\title{
Elaboration of a rest index for a sewing post in a clothing industry
}

DOI: $10.35530 / I T .070 .05 .1543$

AMIRA LAKHAL

YASSINE CHAABOUNI

NEJIB SEJR

FADHEL JAAFAR

MORCHED CHEIKHROUHOU

\author{
ABSTRACT - REZUMAT
}

Elaboration of a rest index for a sewing post in a clothing industry

The textile industry of clothing causes professional diseases in particular the musculoskeletal disorders (MSDs). The application of the culture of technical ergonomics and the methods of ergonomic analysis is to reduce the risk of the diseases. The main objective of this study is to elaborate a rest index which allows giving a recovery period for the sewing post to reduce the risk of MSDs. The method of experimental designs is used to find a model which contains the parameters: the force multiplier, the frequency of technical actions per minute, the posture multiplier and the recovery period multiplier. Then the analysis of results was done by MINITAB Software. The method of General Sewing Data is used to analyze the gesture of the technical actions. The standard ISO 11228-3 is used to determine the posture analysis and the recovery period multiplier. Then, the force analysis is realized by the Borg Score. The model proposed is statistically significant ( $p$ value $=0$ ), representative $\left(R^{2}=96.5 \%\right)$ and validated according to the predictor Fisher test. The practical study was made in two companies of clothing to validate the rest index which varies between 1.14 and 1.22.

Keywords: MSDs, action, ergonomic, force, posture, recovery, time

Elaborarea unui indice de repaos pentru operatorul confecţioner în industria de îmbrăcăminte

Industria textilă şi de îmbrăcăminte provoacă boli profesionale, în special afecțiunile musculo-scheletice (MSD). Aplicarea culturii ergonomiei tehnice și a metodelor de analiză ergonomică se realizează pentru a reduce riscul bolilor. Obiectivul principal al acestui studiu este elaborarea unui indice de repaos, care să permită acordarea unei perioade de recuperare pentru operatorul confecţioner, pentru a reduce riscul de apariție a bolii. Metoda proiectărilor experimentale este utilizată pentru a găsi un model, care să conțină parametrii: multiplicatorul de forță, frecvența acțiunilor tehnice per minut, multiplicatorul de postură și multiplicatorul perioadei de recuperare. Analiza rezultatelor a fost realizată cu software-ul MINITAB. Metoda referitoare la Datele Generale privind Operația de asamblare a fost utilizată pentru a analiza activităţile tehnice. Standardul ISO 11228-3 a fost utilizat pentru a realiza analiza posturii și multiplicatorul perioadei de recuperare. Ulterior, analiza forței a fost realizată prin scorul Borg. Modelul propus este semnificativ din punct de vedere statistic (valoarea $p=0$ ), reprezentativ $\left(R^{2}=96,5 \%\right)$ și validat în conformitate cu testul Fisher predictor. Studiul practic a fost realizat în două companii producătoare de îmbrăcăminte pentru a valida indicele de repaos care variază între 1,14 și 1,22.

Cuvinte-cheie: MSD; acțiune, ergonomic, forță, postură, recuperare, timp

\section{INTRODUCTION}

The textile industry of clothing positions as pillar of Tunisian industry, keeps an important place in the national economy and support a strong contribution in the socioeconomic balances of Tunisia. The sector represents $26.6 \%$ of gross domestic product of Tunisia in 2015 [1]. But, the sector causes professional diseases in particular the musculoskeletal disorders (MSDs). The diseases of MSDs can be located at the level of the hand, the fingers and the wrists, at the level of the elbow, the shoulder, the neck, the back or still at the level of knee and the ankle [2-4]. The diseases of MSDs are connected to a large number of physical constraints (repetitive work, uncomfortable posture...) and psychology organizational (variable work, insecurity of employment...) [5]. The principal objective of this study is to evaluate a rest index to give for the sewing post a percentage of recovery time of the cycle time to minimize the risk of MSDs.

\section{MATERIAL \& METHODS}

The principal objective of this study is to find a model which allows determining a coefficient of rest for sewing post by using parameters chosen from an ergonomic study made according to the standard ISO 11228-3. The method of experimental designs was used to elaborate an index of rest [6]. The tests are determined by the following method:

Ergonomic Index =

$$
=1+\frac{\sum(\mathrm{FM}+\mathrm{FA}+\mathrm{PM}+\mathrm{REM}+\mathrm{RCM}+\mathrm{TM}+\mathrm{AM})}{100}
$$

Knowing that: $F_{M}$ is the force multiplier, $P_{M}$ - the posture multiplier, $R_{E M}$ - the repetitiveness multiplier, $R_{C M}$ - the recovery period multiplier, $T_{M}$ - the multiplier 
duration and $A_{M}$ - the additional multiplier. The variables parameters are $F_{M}, F_{A}, P_{M}$ and $R_{C M}$. The additional multiplier $A_{M}$ was fixed to 0,8 absolute precision and the rhythm is high for more than $80 \%$ of the cycle time [1]. The parameter "duration multiplier" was fixed to 0,5 since, the day time working is greater than 480 minutes for $68 \%$ of Tunisian companies applying more than 8 hour per day.

The cycle time for sewing task is generally greater than 15 seconds [1]. The repetitiveness multiplier was fixed to 1 according to the standard ISO 11228-3. The table 1 summarizes the modality of the different factors of this study.

Table 1

THE VARIOUS FACTORS AND THEIR MODALITY

\begin{tabular}{|l|c|c|}
\hline \multicolumn{1}{|c|}{ Factors } & Modality 1 (-) & Modality 2 (+) \\
\hline $\mathrm{F}_{\mathrm{M}}:$ the force multiplier & 0.5 & 1 \\
\hline $\begin{array}{l}\mathrm{F}_{\mathrm{A}}: \text { The frequency of } \\
\text { technical actions/minute }\end{array}$ & 30 actions/min & 60 actions/min \\
\hline $\begin{array}{l}\mathrm{P}_{\mathrm{M}}: \text { The posture } \\
\text { multiplier }\end{array}$ & 0.5 & 0.7 \\
\hline $\begin{array}{l}\mathrm{R}_{\mathrm{CM}}: \text { The recovery } \\
\text { period multiplier }\end{array}$ & 0.25 & 0.7 \\
\hline
\end{tabular}

The comprehensive method in fact a full factorial conception is selected where this type of plan exhaustive doing all possible combinations of input variable [6]. The value of factor $K$ equal to 4 and the number of level is two levels. The MINITAB software is used to analyze data by choosing the multiple linear regression models with the additive form [7].

$$
Y=b_{0}+\Sigma \beta_{i} X_{i}
$$

After the theoretical elaboration of the rest index, a practical study was made to validate this index for different articles for clothing and for technical uses. The study was realized in tow Tunisian sewing companies. Then, the tests are made in three chains whose two simple lines contain 36 workers and the third has 42 workers and the establishment I S-shaped. The working time in the companies is more than 480 minutes per day with more than 4 hours of working without a recovery period. The steps performed for each article are the following:

- A general observation of the swing posts;

- A gesture analysis according to a predetermined measurement method. The General Sewing Data method [8] was chosen to determine the cycle time and the technical actions of the left and right hands to determine the frequency of technical action per minute;

- A force analysis with the BORG score [9] to determine the force multiplier;

- A posture analysis at the elbow, hand and wrists to determine the posture multiplier;

- Determination of the recovery period multiplier according to the number of hours per day without recovery period according to the standard ISO 11228-3;

- Determination of the rest index according to the proposed model.

\section{RESULTS AND DISCUSSION}

The MINITAB software is used to analyze data, the regression equation is of the following form:

$$
\begin{gathered}
Y=1,27+0,00175 F_{A}-0,104 F_{M}- \\
-0,112 P_{M}-0,0833 R_{C M}
\end{gathered}
$$

According to the regression equation, it is indeed a multiple linear regression model [10-11] with a summation of linearity of different parameters with a constant equal to 1.27. The "p" value for the parameters that included in the model is very low. Therefore, all the coefficients are important in the regression model and are statistically significant. The standard deviation of model "S equal to 0.0098 " and the correlation coefficient " $\mathrm{R}^{2}$ equal to $96.5 \%$ ", while the error is equal to " $3.5 \%$ ", less than " $5 \%$ ". The values of the coefficient " $R$ " indicate that the model is better. As a conclusion, the calculated answers will be highly correlated with experimental answers. The value of " $\mathrm{R}^{2 \text { " }}$ is equal to $96.5 \%$, so, the quality of this model is better. In a hypothesis test, the decision can be based on the probability value "p value" [12-13]. In fact, if the value of " $p$ " is less than or equal to a predetermined level of significance (alpha $=0.05$ ), so the model is statistically significant. If not, we must reject the model. According to the model suggested " $\mathrm{P}=0$ ", so the model is statistically significant [4-13]. According to the model " $\mathrm{P}=0$ ", well observed that the "F statistic equal 75.23" is a significant value higher than "F critical $=3.357$ ", which satisfies the predictor Fischer test. The predictor Fischer test "HO" does not describe the variation of test results. The predictor Fischer test "F" gives an ideal probability "prob F" rejects the null hypothesis. Below " $5 \%$ ", the model cannot be rejected in this case; "prob $\mathrm{F}$ " is equal to "3.9\%". Therefore, the model is representative. Observing the interactions given by statistical analysis as shown in figure 1, there are no interactions between the overall input parameters.

Figure 2 indicates the effects of the variables over the response. In fact, the parameter "Frequency of technical actions/minute" has a positive effect over the response with a statistical coefficient equal to 0.00175 . However, the parameters "force multiplier", "posture multiplier" and "recovery period multiplier" have a negative effect over the response with the successively coefficient: "0.104"; "0.112" and "0.0833".

The practical study was realized for different articles for clothing and for technical uses, the table 2 shows the results.

Textile and clothing industry has been known for its incremental changes and the multiple organizational disruptive changes [16]. MSDs are a major health problem in the work place and especially in the clothing 


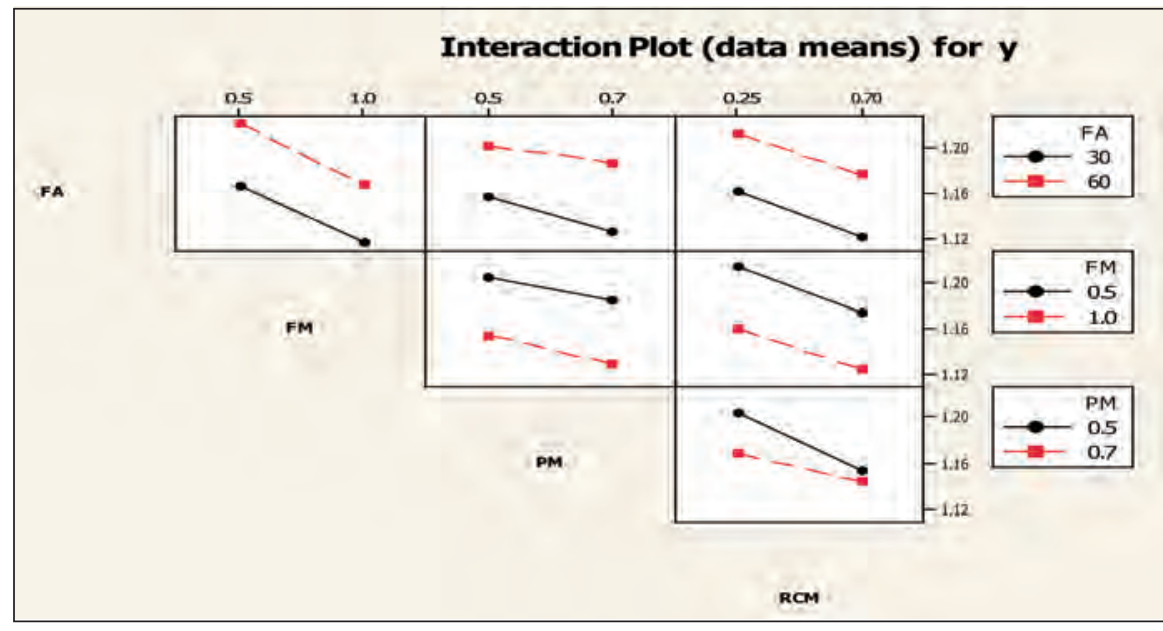

Fig. 1. Diagram of interaction Plot between the variables

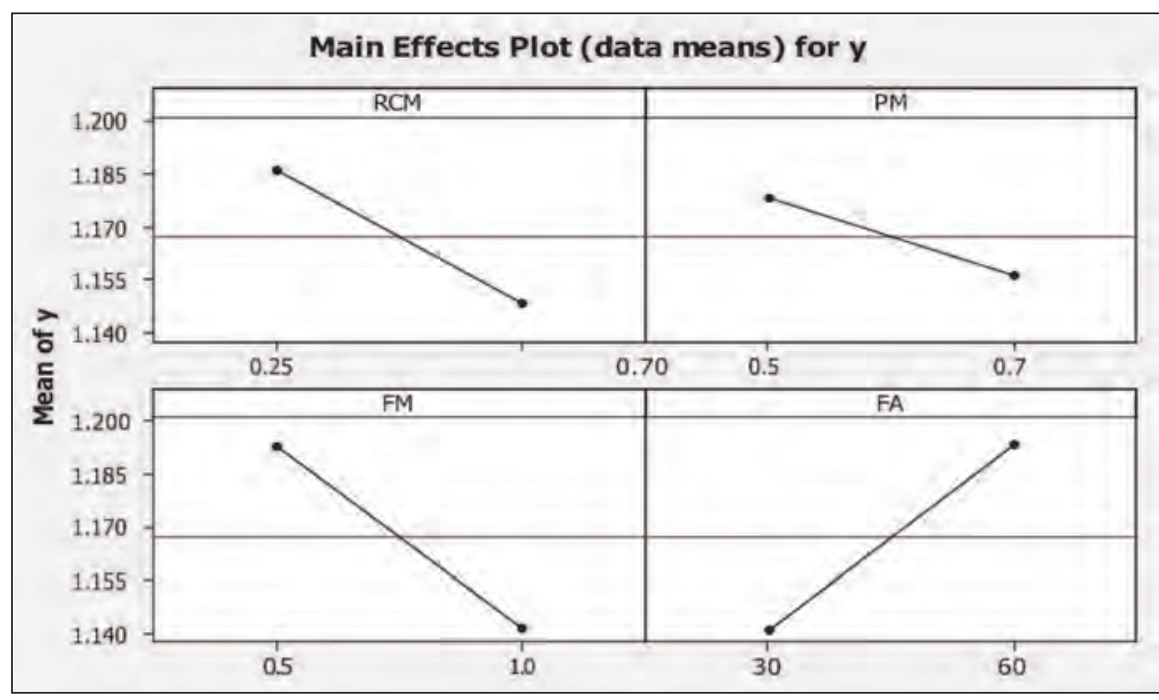

Fig. 2. Diagram of the principal effects of the variables over the rest index level competence required [4]. Then, the nature of the sewing machine usually requires a sitting posture and the assembly task requires pushed to the right and the left hand [7]. The analysis of sewing post shows that the MSDs are a major problem with $78 \%$ of the population has problems of the lower luck, $76 \%$ in the hands and wrists, $52 \%$ in the neck and $48 \%$ in the shoulders. The frequent use of two hands throughout the cycle of working for a stitching task increases the frequency of technical actions. The level of the force increases by the action of sewing in the cycle and by the use of the tools and the materials. The time of the cycle working and the duration of daily work in the company affected the risk of MSDs, as well as posture knowing that the stitching station is major cause for the risk [1].

According to these factors, a rest index has been developed which allows giving a recovery time for each post. This index is defined according to the following parameters; frequency of technical actions that varies according sector and represent the leading cause of occupational diseases. The major causes of MSDs are physical exertions, repetitive movements and awkward position [15]. Other causes of the MSDs diseases are related to the following factors that machine incidents, machine breakdown, the light rate of work and lack of autonomy, the level of concentration and the to the number of gestures of the left and right hands in the cycle of a stitching task. The second parameter is the level of force that depends on the complexity of the task and the used tools. The next parameter is the posture multiplier which is related only to the movements of the hands, wrists and elbows. The last parameter is the recovery multiplier which is related

APPLICATION OF THE REST INDEX IN TWO COMPANIES OF CLOTHING FOR DIFFERENT ARTICLES

\begin{tabular}{|l|l|c|c|c|c|c|c|c|}
\hline Companies & \multicolumn{1}{|c|}{ Articles } & $\begin{array}{c}\text { Number of } \\
\text { operations }\end{array}$ & $\begin{array}{c}\text { Total time } \\
\text { (s) }\end{array}$ & RcM & $\begin{array}{c}\text { Pm } \\
\text { (min-max) }\end{array}$ & $\begin{array}{c}\text { FA } \\
\text { (min-max) }\end{array}$ & $\begin{array}{c}\text { FM } \\
\text { (min-max) }\end{array}$ & $\begin{array}{c}\text { Rest index } \\
\text { (min-max) }\end{array}$ \\
\hline \multirow{2}{*}{ Companies 1} & Casual trousers & 45 & 1334 & 0.53 & $0.5-0.6$ & $32-70$ & $0.6-0.83$ & $1.14-1.22$ \\
\cline { 2 - 9 } & Men jacket & 61 & 2293.44 & 0.53 & $0.5-0.6$ & $32-63$ & $0.75-0.77$ & $1.14-1.19$ \\
\hline \multirow{5}{*}{ Companies 2 } & Sport trousers & 23 & 586.4 & 0.55 & $0.5-0.6$ & $35-57$ & $0.75-0.81$ & $1.14-1.18$ \\
\cline { 2 - 9 } & Support for broom & 10 & 366.86 & 0.55 & $0.5-0.6$ & $41-55$ & $0.75-0.8$ & $1.15-1.17$ \\
\cline { 2 - 9 } & BAG & 10 & 405.4 & 0.55 & $0.5-0.6$ & $39-61$ & $0.76-0.84$ & $1.15-1.18$ \\
\cline { 2 - 9 } & Guettre & 19 & 665.74 & 0.55 & $0.5-0.6$ & $41-56$ & $0.75-0.78$ & $1.15-1.18$ \\
\hline
\end{tabular}


to the break time of the work and which influences the work rate.

The rest index was developed based on these parameters in order to reduce the risk of MSDs for a stitching station. This index depends on the task, the equipment and the tools used and also on the company itself in terms of job organization and working time. The use of this index must be done by increasing this index by the cycle time of a stitching task to give a percentage of recovery time for the operator. The rest index is valid for stitching operations that have a cycle time greater than 15 s and a working time of more than 8 hours per day.

The practical application for the articles studied indicates that the index of rest varies between 1.14 and 1.22. This shows that it takes a markup between $14 \%$ and $22 \%$ of the cycle time to give a recovery time to the workforce.

The ergonomic indexes found (14\%-22\%) are quite high compared with the ergonomic index for the automotive field which varies according to the manufacturer between $7 \%$ and $10 \%$ [1]. Indeed the index of rest depends on the complexity of the task which influences the frequency of the technical actions of two hands. Where this frequency varies between 32 and 70 actions per minute depending on the operation to be performed and the phase of the operation; this means that a preparation operation requires fewer actions than a mounting phase. In addition, the number of pieces to be stitched and the size of pieces influenced the frequency of the technical actions and the time of the stitching operation [8]. The force multiplier $F_{M}$ varies between 0.6 and 0.81 , in fact, this level depends on the frequency of the technical actions, the percentage of technological time (sewing action) in the cycle and tools used such as the chisel. The posture multiplier $P_{M}$ varies between 0.5 and 0.6 depending on the position of the elbows, hands and handles and also according to the percentage of awkward position in the work cycle of a task. The recovery multiplier time $R_{C M}$ depends on the break time according to the company's timetable. In fact, according to the ISO 11228-3 standard, every 60 s requires 10 s of recovery to have a coefficient $R_{C M}$ equal to 1 . The recovery makes it possible to rest the upper limbs of the workforce in order to minimize the risk of MSDs.

\section{CONCLUSION}

Tunisian garment sector is the most providers of occupational diseases including MSDs, despite its importance in the economy sector. This study was done to determine a rest index used as a cycle time increase multiplier of an operation to give a percentage of recovery time to the workforce to minimize the risk of MSDs. The proposed index is statistically significant since the value of $R^{2}$ is 96.5 and the error is $4.5 \%$ indicating that the model is representative. Thus, the value of $F$ statistic corresponds to the predictor Fischer test. The practical application of the index in various article and following the results found, the index of rest varies from 1.14 to 1.22 . This variance mainly depends on the complicity of the task, the phase of the operation (preparation, mounting...), the size and number of pieces, the percentage of technological time in the cycle, the tools used, the posture and the work timetable and the break time set by the company.

The proposal of a rest index is a solution to minimize the risk of MSDs. As well as the application of the ergonomic culture on the technical scale is necessary in the garment industries using ergonomic analysis methods and applying the ergonomic design approach to take preventive measures to achieve the optimal layout Workstations allowing the best organization of the post with a comfortable posture to reduce the time constraints and improve working conditions and increase the productivity and thus reduce the risk of MSDs.

\section{REFERENCES}

[1] Lakhal, A., Sejri, N., Chaabouni, Y., Jaafar, F., Cheikhrouhou, M., Ergonomic analysis in a company of clothing and evaluation of an ergonomic index related to Msds, In: International Journal of Research and Reviews in Applied Sciences, 2017, 31, 2, 46-53

[2] Barbara, A., Diana, S., Monore, K., Lawrence, J., Work-related musculoskeletal disorders: Comparaison of data sources for surveillance, In: American Journal of Industrial Medicine, 1997, 31, 5, 600-608

[3] David, G.C, Ergonomic methods for assessing exposure to risk factors for work-related musculokeletal disorders, In: Ocuupational Medecine, 2005, 55, 3, 190-199

[4] Ghram, R., Fournier, C., Khalfallah, T., Francis, S., Analyse des facteurs socioculturels et survenue des troubles musculosquelettiques: le cas des couturières en Tunisie, In: Perspectives interdisciplinaires sur le travail et la santé, 2010, 1, 21, http://doi.org/10.4000/pistes.2459

[5] Aptel, M., Aublet-Cuvelier, A., Cnockert, J-C., Les troubles musculosquelettiques du membre supérieur liés au travail, In: Revue du Rhumatisme, 2002, 17, 3, 455-469

[6] Dominique, C., Plan d'expérience factoriels: construction et propriétés des fractions de plans, Springer-Verlag Berlin Heidelberg, $1^{\text {th }}$ Edition, Pays de l'Adour, France, 1996

[7] Halpern, C.A., Kenneth, D., Design and implantation of participatory ergonomics program for machine sewing tasks, In: International journal of industrial ergonomics, 1997, 20, 6, 429-440

[8] Lakhal, A., Sejri, N., Chaabouni, Y., Jaafar, F., Cheikhrouhou, M., Analysis of the Sewing Time in a Clothing Industry. In: Transylvanian Review, 2017, 27, 16, 3602-3610

industroำ textillă 2019, vol. 70, no. 5 
[9] Borg, G.A., Psycho-physical bases of perceived exertion, In: Medicine and Science in Sports and Exercise, 1982, $14,5,377-387$

[10] Douglas, C.M., Elizabet, A.P., Geoffey G.V., Introduction to linear regression, WILEY, $1^{\text {th }}$ Edition, Arizona, India, 2015

[11] Khedher, F., Jaouachi, B., Waste factor evaluation using theoretical and experimental jean pants consumptions, In: The Journal of The Textile Institute, 2014, 106, 4, 402-408

[12] Maatouk, I., Msahli, S., Zidi, M., Sakli, F., Numerical simulation of yarn bending: Statistical optimization, In: International Journal of Applied Research on Textile, 2015, 3,2, 49-59

[13] Romdhani, Z., Hamdaoui, M., Chebi, A., Jendoubi, M., Effect of paste properties as inkjet printing film and Mathematical Model to Follow the Kinetic of Wetting Phenomeno, In: Industria Textila, 2018, 69, 1, 65-74, http://doi.org/10.35530/IT.069.01.1366

[14] Daniel, J.B., Kristopher, J.P., Patrick, J.C., Computational tools for probing interactions in Multiple Linear Regression, Multilevel Modeling and Latent Curve Analysis, In: Journal of Educational and Behavioral Statistics, 2006, 31, 3, 437-448

[15] Julitta, S., Boschma., Monique, H.W., Henk., F. Vander., Molen., Use of ergonomic measures related to musculoskeletal complains among constinction workers: A 2-year follow-up study, In: Journal Elsevier, safety and health at work, 2015, 6, 2, 90-96

[16] Turdor, L., Change in Textile and Clothing Industry, In: Industria Textila, 69, 1, 37-43, http://doi.org/ 10.35530/IT.069.01.1449

\section{Authors:}

AMIRA LAKHAL, NEJIB SEJRI, FADHEL JAAFAR, YASSINE CHAABOUNI, MORCHED CHEIKHROUHOU

University of Monastir, Textile Engineering Laboratory of ISET KsarHellel, 5070, Monastir, Tunisia

Corresponding author:

AMIRA LAKHAL

e-mail: a_mira1987@live.fr 